\title{
EESTI KEELE RIIKLIKE TASEMETÖÖDE TEKSTIMÕISTMISÜLESANNETE ANALÜÜS
}

\author{
Triinu Kärbla, Krista Uibu, Mairi Männamaa
}

\begin{abstract}
Ülevaade. Teksti mõistmine on protsess, mis eeldab madalama ja kõrgema tasandi oskuste rakendamist. Selles artiklis analüüsitakse 2013.-2015. aastal tehtud 6. klassi eesti keele riiklike tasemetööde ülesandeid, et selgitada välja, millistel tekstimõistmistasanditel hinnatakse õpilaste oskusi. Analüüsist selgub, et ülesannetes keskenduti peamiselt õpilaste faktiteadmiste kontrollimisele. Seejuures olid 2014. ja 2015. aasta tasemetööd koostatud nii, et üle poole kõikidest ülesannetest (2014. a 76\%; 2015. a 57\%) mõõtsid õpilaste sõnasõnalist tekstimõistmist. 2013. aasta tasemetöös oli nende ülesannete osakaal $43 \%$. Kolme aasta tasemetööde võrdluses eristus ainult üks ülesanne (2013. aastal), milles õpilane pidi rakendama teksti hindamisel taustteadmisi. Uurimusest ilmneb, et tasemetööde tekstimõistmisülesanded ei ole piisavalt mitmekesised, et hinnata õpilaste eri tasandite oskusi. Kui tasemetööd koosnevad valdavalt faktiteadmisi kontrollivatest ülesannetest, mis nõuavad õpilaselt lihtsate järelduste tegemist, siis keskenduvad ka õpetajad lugemistundides eelkõige madalama tasandi oskuste arendamisele ja õpilaste kõrgeima tasandi oskuste kujundamine jääb tagaplaanile. Kuna kõrgemal tasandil tekstimõistmine on üks peamisi oskusi edukaks toimetulekuks akadeemilises ja igapäevaelus, tuleks õppeprotsessis sellele rohkem tähelepanu pöörata.
\end{abstract}

Võtmesõnad: riiklik tasemetöö, tekstimõistmistasand, põhikool, eesti keel

\section{Sissejuhatus}

Teksti mõistmine on kompleksne protsess, mille käigus antakse tekstile tähendus (Bursuck, Damer 2011, Roe, Smith 2012). Teksti mõistmist mõjutavad õpilase keelelised võimed, sõnavara ja eelteadmised (Nation jt 2010, Broek, Espin 2012). Eelteadmised võimaldavad luua teksti mõistmiseks vajalikke seoseid uue ja vana info vahel (Schroeder 2011). Keeleliste võimete, sõnavara ja eelteadmiste kõrval sõltub 
tekstist arusaamine ka kriitilise mõtlemise ja järeldamisoskusest ning teadmistest selle kohta, mida laps juba teab, st metakognitiivsetest oskustest (Kostons, Werf 2015, Pintrich 2002). Teksti mõistmiseks ja loetust tervikpildi saamiseks töödeldakse teksti nii madalamal tasandil (nt sõnade dekodeerimine, sõnavara tundmine) kui ka kõrgemal tasandil (nt info analüüsimine, seostamine ja hindamine) ning eri tasandi oskusi kombineerides (Angosto jt 2013, Applegate jt 2002).

Varasemad uuringud on näidanud, et teksti mõistmise raskustega lastel on kehvem sõnade tundmise ja loetu kodeerimise oskus, nad ei loe teksti ladusalt ning kasutavad sõnavara ja tekstimõistmise strateegiaid piiratult (Sencibaugh, Sencibaugh 2015). Samas ei taga eakohane lugemisoskus tekstist arusaamist ja teksti põhjal järelduste tegemist (Nation jt 2010). Lapsed, kellel on raske teksti mõista, töötlevad oma arusaamist järgides teksti pealiskaudsemalt (Oakhill, Yuill 1996), meenutavad tekstis sisalduvat infot vähem täpselt ja teevad meenutamisel rohkem vigu (Carretti jt 2005). Seevastu parema tekstimõistmisoskuse ja verbaalse võimekusega õpilased kodeerivad ja seostavad tekstipõhist infot paremini (Schroeder 2011).

Tekstist arusaamist mõjutavad eri tegurid: teksti lugeja, tekst, lugeja püstitatud ülesanne ja teksti mõistmise kontekst (Bursuck, Damer 2011). Siinses artiklis keskendutakse tekstimõistmistasandeid hindavatele ülesannetele 2013.-2015. aasta 6. klassi eesti keele riiklikes tasemetöödes. Nende tasandite hindamine võimaldab välja selgitada võimalikud raskused tekstist arusaamisel. Kogutud teadmiste abil saab õpetamist paremini planeerida, arendada teksti mõistmist ja õpetada teksti mõistmist toetavaid strateegiaid (Sencibaugh, Sencibaugh 2015).

\section{Teksti mõistmine ja selle hindamine}

\subsection{Tekstimõistmistasandid}

Teksti mõistmiseks tuleb lugemisprotsessis rakendada madalama ja kõrgema tasandi oskusi (Angosto jt 2013). Sõltuvalt rakendatavate oskuste keerukusest mõistetakse teksti eri tasanditel. Teksti mõistmise klassifitseerimiseks on erinevaid võimalusi. Neist lihtsaimaks on kahetasandiline jaotus - sõnade dekodeerimine ja loetu mõistmine - ning keerukaimaks selline liigitus, kus iga tasand hõlmab omakorda eri raskusastmeid. Näiteks eeldab info hankimine esimesel tasandil selgelt eristuva info leidmist tekstist, seevastu kuuendal tasandil vaevu märgatavate detailide tähelepanemist (vt ka Tire jt 2010). Üheks levinumaks klassifikatsiooniks võib pidada Basabara ja tema kolleegide (2013) loodud kolmetasandilist tekstimõistmismudelit: sõnasõnaline tasand, järeldav tasand ja hindav tasand. Ka rahvusvahelises võrdlusuurimuses "National Assessment of Educational Progress" (NAEP 2008) ning OECD dokumentides (vt Tire jt 2010) on kasutatud sarnast liigitust, kuid teisi nimetusi: info hankimine, seostamine ja tõlgendamine, arutlemine ja hindamine.

Madalamal ehk sõnasõnalise mõistmise tasandil suudab lugeja aru saada tekstis sisalduvast selgest infost ning teha lihtsaid tekstil põhinevaid järeldusi (Kibui 2012, NAEP 2008). Sellist mõistmist iseloomustab teksti pinnapealne lugemine, kus loetut ei seostata eelteadmiste ja kogemustega (Butcher, Kintsch 2012). PISA raamdokumendi (OECD 2008) järgi on madalaima tasandi tunnuseks eelkõige oskus hankida tekstist infot. Sellises ülesandes peab õpilane aru saama küsimusest, mis talle esitatakse, ning leidma seejärel tekstist või tabelist sõnasõnalise ja 
küsimusele sobiva vastuse (Applegate jt 2002). Näiteks, tekstis on kirjas, et loo peategelane käib 6. klassis, ning selle info mõistmist kontrollitakse küsimusega “Mitmendas klassis käib peategelane?". Või teine näide: tekstis on kirjas, et isa auto ei käivitunud ja ta jäi tööle hiljaks. Tekstipõhist lihtsat järeldamist nõuab küsimus "Miks jäi isa tööle hiljaks?".

Tekstimõistmise järeldaval tasandil analüüsitakse teksti sisu, arutletakse lõikude ja seoste üle ning tehakse loetu põhjal keerukamaid järeldusi (Basabara jt 2013, Mayer 2002). Sellel tasandil on fookuses eri sündmuste, tegevuste ja väidete võrdlemine ja sidumine tervikuks, samuti tekstitühikute täitmine ning uue info seostamine lugeja eelteadmistega (Butcher, Kintsch 2012). Teksti mõistmist järeldaval tasandil iseloomustab see, kui õpilane saab aru tegelaste käitumismotiividest ja otsustest, oskab neid tõlgendada ning luua põhjuse ja tagajärje seoseid (NAEP 2008, OECD 2008). Applegate'i jt (2002) sõnul kuulub järeldavale tasandile näiteks niisugune ülesanne, kus kirjeldatakse kahte tegelast ja nende elusündmusi. Keerulist järeldamist teksti põhjal nõuab küsimus "Miks said neist kahest tegelasest sõbrad?”. Ka PISA raamdokumendis (OECD 2008) kirjeldatakse ülesandeid, mille lahendamiseks läheb tarvis järeldaval tasandil mõistmist. Selliste ülesannete hulka liigitatakse tekstide pealkirjastamine, tegelaste ja nende tegevuste kirjeldamine, võrdlemine ja vastandamine, kaardi või joonise kasutuseesmärgi selgitamine ja kindlate mõõtude leidmine diagrammilt.

Tekstimõistmise kõrgeimal ehk hindaval tasandil vajab lugeja peale kahe eelneva tasandi oskuste (sõnatähenduse tundmise, info analüüsimise, tekstitühikute täitmise) ka oskust mõista teksti laiemalt, st lugeda ridade vahelt, tõlgendada sisu ning väljendada arvamust autori võimalike kavatsuste kohta (Kibui 2012). Lugejalt oodatakse pädevust seostada tekstis sisalduv info oma arusaamade ja kogemustega ning teistest allikatest pärit teadmistega. Sellel tasandil suudab lugeja, toetudes eelteadmistele, hinnata kriitiliselt teksti usaldusväärsust ning väidete ja põhjenduste kvaliteeti (NAEP 2008, OECD 2008). Hindava tasandi ülesannete ja küsimustega mõõdetakse oskust leida alternatiivseid tõendeid autori väidete põhjendamiseks ning mõista ja mõtestada autori eesmärke. Sellist tüüpi ülesanne on näiteks niisugune, kus tekstis kirjeldatakse kahe õpilase käitumist klassiekskursioonil ning lugeja hindamisoskust kontrollitakse küsimusega "Kui Sa oleksid õpetaja, siis kumba õpilast sooviksid oma klassi? Põhjenda oma arvamust!” (vt Applegate jt 2002).

Õpilase tekstimõistmistaseme hindamisel on oluline kontrollida kõikide tasandite oskusi (Hogan jt 2011). Puudujääk madalama tasandi oskustes (nt kitsas sõnavara) võib olla peamine põhjus, miks õpilane ei mõista teksti kõrgemal, st järeldaval ja hindaval tasandil. Kui teksti mõistmine sõnasõnalisel tasandil õpilasele probleeme ei valmista ja probleemid ilmnevad alles järeldaval tasandil (nt õpilane ei suuda teksti analüüsida ja loetu põhjal järeldusi teha), võibki probleem olla üksnes järeldava tasandi oskustes.

\subsection{Teksti mõistmise hindamine}

Teksti mõistmist hinnatakse eri eesmärkidel (Põhikooli riiklik õppekava 2010). Üks eesmärke võib olla välja selgitada õpilaste teadmised või arusaamad loetu kohta ning siduda need varasemate teadmiste ja kogemustega ning nendega, mis on olulised oleviku ja tuleviku jaoks. Sellisel juhul eelistavad õpetajad ülesandeid, 
millega kontrollitakse laste teadmisi teema kohta ja mis on vajalikud konkreetses ainetunnis (Mercer 2008). Hindamist võib alustada sellest, et esmalt selgitatakse välja õpilaste põhiteadmised ning luuakse seosed nähtuse igapäevase ja teadusmõistelise tähenduse vahel (Pianta, Hamre 2009, Võgotski 2014 [1934]). Seejärel seostatakse varasem teadmine uuega, jagatakse ideid ja arusaamu ning põhjendatakse neid (Kostons, Werf 2015, Pintrich 2002).

Uurijaid on huvitanud peamiselt see, mis tüüpi ülesandeid õpetajad mõistmise arendamiseks pakuvad ja mis tüüpi küsimusi õpilastele esitavad (Thompson 2008). Eri tüüpi ülesannete ja küsimuste kasutamine võimaldab õpilasel väljendada oma teadmisi ja ideid erinevatel tekstimõistmistasanditel (Mercer 2008). Paraku on üks enim levinud viis hinnata teksti mõistmist, esitades küsimusi teksti sisu kohta. Õpetajad koostavad sageli küsimusi teadmiste kontrolli eesmärgil, nii et vastus on neile endile täpselt teada ja selge. Sellised küsimused eeldavad õpilaselt tihti lühivastuseid, kusjuures vastuste täiendamist ja laiendamist tagasisidena õpetajad peaaegu ei kasuta (Uibu jt 2016). Peamine eesmärk on otsene õpetamine ja õppimine, mis nõuab õpetajalt õpilaste vähest suunamist. Uurinud Suurbritannia õpetajaid, leidsid Mercer ja Dawes (2014), et isegi esimese kooliastme klassides esitasid õpetajad teadmiste kontrollimiseks tüüpiliselt kinnisi küsimusi. Laste vastustes hindasid nad korrektsust, täpsust ja asjakohasust, mis alati ei stimuleerinud kaasamõtlemist. Parimad õpitulemused emakeeles avaldusid seevastu õpilastel, kelle õpetajad kasutasid tunnis sageli arutelusid ja avatud küsimusi, soodustades niiviisi õpilaste metakognitiivsete oskuste arengut (Mercer 2013, Mercer, Dawes 2014).

Et toetada arusaamisega õppimist (Pianta, Hamre 2009), tuleks lugemistunnis kasutada erinevaid tehnikaid: kokkuvõtte tegemist ja tekstist ülevaate andmist, täpsustavate küsimuste esitamist varem õpitu meenutamiseks ja seoste loomiseks ning avatud küsimuste esitamist eesmärgiga suunata õpilast mõtlema (Nystrand jt 2003, Uibu jt 2016). Näiteks on selgitusi eeldavad küsimused (Kuidas? Miks?), hinnangute andmine teiste ja enda tegevusele, aga ka oma tegevust kirjeldama ja põhjendama suunavad küsimused (Mida tehti selleks, et ...?) vajalikud tekstimõistmise kõrgema tasandi arendamiseks. Üks võimalus on ka õpetada argumenteerimisvõtteid, millega suurendatakse või vähendatakse avaldatud ideede aktsepteeritavust (Babic, Baucal 2011). Argumenteerimist peetakse olulisimaks võtteks kriitilise mõtlemise ja arutlusoskuse kujundamisel. Seejuures on ka õpetajal võimalik õppida laste vastustest (Mercer 2008).

Õpilase keeleteste ja tasemetöid hindab õpetaja. Tema ülesanne on arvestada kokku õpilase positiivsed vastused varem omandatud teadmiste kohta või nende taustal ning hinnata õpilase akadeemiliste teadmiste taset (Üleriigiline tasemetöö 2013, 2014, 2015). Hindamine hõlmab õpetaja otsust vastuse korrektsuse kohta ja annab õpilasele teadmise, kas tema vastus oli õige või väär, otsene või kaudne (Mercer, Dawes 2014). Hindamisel saab õpetaja kasutada erinevaid tagasiside võimalusi: vastus on korrektne/ebakorrektne, sobilik/sobimatu ja täielik/osaline. Kui eesmärk on õpilasi võrrelda, siis formuleeritakse ülesanded nii, et neid oleks lihtne kontrollida. Õpetaja saab hinnata vastused üsna rutiinselt kas positiivseks või negatiivseks või teha otsuse vastuse täiendamise kohta. Keeleõpetaja hindab vastustes sageli ka nende grammatilist korrektsust (Margutti, Drew 2014). Kuna teksti mõistmine on keerukas protsess, tuleb kasutada eelnimetatud võimalusi ka tekstimõistmistasandi hindamiseks. 


\section{Uurimuse eesmärk ja uurimisküsimused}

Et selgitada välja õpilaste tekstimõistmistase, on tähtis, et keeletestid ja riiklikud tasemetööd sisaldaksid ülesandeid ja küsimusi, millega hinnatakse erinevaid oskusi. Need peaksid võimaldama kontrollida õpilaste faktiteadmisi, analüüsimis- ja järeldamisoskust ning seda, kuidas teadmisi rakendada. Siinses artiklis analüüsitakse 6. klassi eesti keele riikliku tasemetöö ülesandeid kolmel aastal (2013-2015) eesmärgiga selgitada välja, mis tasanditel hinnatakse õpilaste tekstimõistmisoskust. Uurimuse põhiküsimused on järgmised.

1. Milline on erinevate tekstimõistmisülesannete osakaal (tekstimõistmine sõnasõnalisel, järeldaval ja hindaval tasandil) tasemetöödes?

2. Milliseid ülesandeid kasutatakse tasemetöödes õpilaste tekstimõistmise hindamiseks sõnasõnalisel, järeldaval ja hindaval tasandil?

3. Mis tüüpi tekstimõistmisülesanded eristuvad tasemetöödes?

\section{Meetod}

\subsection{Tasemetööde ülesanded}

Analüüs hõlmas 6. klassi eesti keele tasemetööde tekstimõistmisülesandeid. 2013. aasta tasemetöös oli selliseid ülesandeid neli: kuulamisülesanne koos valikvastusülesandega (kümme küsimust), järjestusülesanne, küsimuste koostamine ning lünkteksti täitmine tabeli põhjal; kokku oli 21 alaülesannet. Esimeses ülesandes pidid õpilased kuulama Jaanus Vaiksoo pala "Kust Kanamatsi künkad endale nime said”, mis koosnes 14 lausest (keskmine pikkus 13,07 sõna) ja 183 sõnast (keskmine pikkus 6,25 tähte). Teises ülesandes tuli õpilasel analüüsida uudist ja järjestada selles kuus tekstilõiku nii, et tekiks loogiline tervik pealkirjaga "Tallinna teletorni maskott sai nimeks Eti”. Uudis koosnes kaheksast lausest (keskmine pikkus 11 sõna) ja 88 sõnast (keskmine pikkus 7,7 tähte). Tasemetöö kolmandas ülesandes pidi õpilane koostama neli küsimust eelmise ülesande uudise kohta (Kes? Millal? Kuidas? Miks?). Neljandas tekstimõistmisülesandes oli vaja lugeda tabelit ning täiendada selle põhjal 6 lauset.

2014. aasta tasemetöö sisaldas kolme tekstimõistmisülesannet 25 alaülesandega. Ülesannete jaotus oli järgmine: kuulamisülesanne koos lünkülesandega (vastusepank), lünkteksti täitmine tabeli ja diagrammi põhjal ning valikvastusülesanne. Kuulamisülesanne koosnes kahest osast. Esmalt pidid õpilased kuulama Kristel Vilbaste juttu “Tuletegemine” ja seejärel täitma kuuldu põhjal kümme lünka. Kuulamispala koosnes 22 lausest (keskmine pikkus 11,14 sõna) ja 245 sõnast (keskmine pikkus 6,38 tähte). Lünkadesse sobivad sõnad olid esitatud ülesande lõpus õiges käändes vastuste paaridena. Näiteks pidi õpilane valima lünka sobiva sõna paarist rauda-kruusa. Teises tekstimõistmisülesandes tuli võrrelda diagrammil "Arvutikasutuse valdkonnad" viit tulpa poiste ja tüdrukute arvutikasutuse kohta (märgised tulpade all olid järgmised: mängimine, töö, õppimine, kirjutamine ja joonistamine). Seejärel tuli õpilasel täita viis lünka. Kolmandas ülesandes pidi õpilane lugema reklaami ja valima kümne valikvastuse hulgast lause algusele sobiva lõpu. Igale algusele järgnes kolm varianti, millest üks oli õige. 
2015. aasta tasemetöö sisaldas kahte tekstimõistmisülesannet, sh 21 alaülesannet. Nende hulgas oli kuulamisülesanne koos valikvastusülesandega (õiged-valed vastused) ning lünkteksti täitmine tabeli ja diagrammi põhjal. Esimeses ülesandes kuulasid õpilased Asta Kassi lugu “Kärbse päev", mis koosnes 34 lausest (keskmine pikkus 11,69 sõna) ja 374 sõnast (keskmine pikkus 5,34 tähte). Seejärel pidi õpilane tegema kuuldu põhjal otsuse, kas väited teksti kohta on õiged või väärad (Otsusta kuuldud teksti põhjal, kas väide on õige või vale. Tee vastavasse kasti rist). Teises tekstimõistmisülesandes tuli võrrelda tabelis, diagrammil ja pildil esitatud infot ning täita selle põhjal lüngad.

\subsection{Andmeanalüüs}

Analüüsitud eesti keele 6. klassi tasemetööd saadi AS Innove kodulehelt. Tekstimõistmisülesannete tasandite liigitamisel võeti aluseks rahvusvaheliste võrdlusuuringute NAEP ja PISA tekstimõistmistasandid (NAEP 2008, OECD 2008, Tire jt 2010). Esimese ehk sõnasõnalise tasandi ülesandeks liigitati ülesanne, kus otsustamiseks vajalik info sisaldus tekstis ja õpilane pidi selle kuuldu või loetu põhjal üles leidma või seda meenutama. Esimese tasandi ülesandes ei eeldatud oskust teksti analüüsida ega järeldusi teha. Teise ehk järeldava tasandi ülesandeks määrati analüüsimist ja järeldamist nõudvad ülesanded, kus õpilane pidi võrdlema tekstis sisalduvat infot või kasutama analüüsimisel ja järelduste tegemisel varem omandatud taustteadmisi. Kolmanda ehk hindava tasandi ülesandeks liigitati sellised ülesanded, kus õpilane pidi taustteadmisi rakendades andma hinnangu loetu kohta.

Aastate lõikes oli analüüsitavate tekstimõistmisülesannete koguhulk järgmine: 2013. a 21, 2014. a 25 ja 2015. a 21 alaülesannet. Kui lause koosnes mitmest lüngast, kus õpilane pidi vastama samale küsimusele/väitele, arvestati lüngad üheks alaülesandeks. Näiteks kodeeriti lüngad lauses "6o meetri teatejooksu võistkonda (2 poissi ja 2 tüdrukut) kuuluvad ........, ......., ........ ja ........" üheks alaülesandeks (vt 2013. a tasemetööd).

Kõiki eespool kirjeldatud tekstimõistmisülesandeid (küsimused, lüngad ja väited) analüüsiti suunatud teemaanalüüsi meetodil (Ryan, Bernard 2000). Uurimuse usaldusväärsuse suurendamiseks analüüsisid kaks autorit kõigepealt ülesandeid individuaalselt ja jaotasid need tekstimõistmistasandi järgi kolme kategooriasse: 1) mõistmine sõnasõnalisel tasandil, 2) mõistmine järeldaval tasandil, 3) mõistmine hindaval tasandil. Seejärel võrdlesid autorid oma hinnanguid ja arutasid läbi erinevused. Toetudes teooriale, saavutati konsensus. Lõpuks arvutati iga tasandi ülesannete summa, mida kasutatakse järgnevates analüüsides.

\section{Tulemused}

Kolme kategooria (sõnasõnaline, järeldav ja hindav tasand) tekstimõistmisülesannete osakaal kolme aasta eesti keele tasemetöödes on esitatud joonisel 1. 


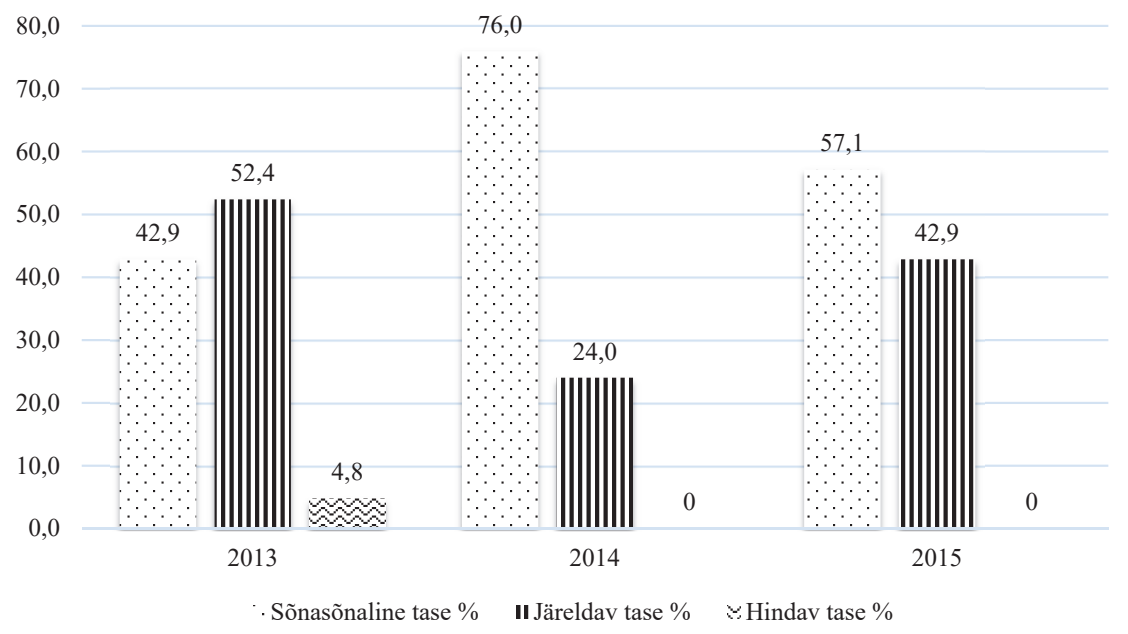

Joonis 1. Tekstimõistmisülesannete osakaal tasemetöödes

Analüüsi käigus selgus, et ainult 2013. aasta tasemetöös olid esindatud kõikide tekstimõistmistasandite ülesanded: $42,9 \%$ ülesannetest kuulus sõnasõnalisele tasandile, 52,4\% järeldavale tasandile ja 4,8\% hindavale tasandile. Seevastu 2014. ja 2015. aasta tasemetöödes olid ainult sellised ülesanded, millega hinnati õpilaste oskust mõista teksti sõnasõnalisel ja järeldaval tasandil. Kõrgeimat tekstimõistmistasandit kontrollivaid ülesandeid nende aastate eesti keele tasemetöödes ei olnud. Ülekaalus olid sõnasõnalise tasandi ülesanded: 2015. aasta tasemetöös oli selliseid ülesandeid natuke üle poole $(57,14 \%)$ ja 2014 . aasta tasemetöös veidi rohkem kui kolmveerand (76\%). Kõige vähem leidus tekstimõistmise sõnasõnalise tasandi ülesandeid 2013. aasta tasemetöös (42,9\%). Need ülesanded eeldasid lugemispalas sisalduva info selgesõnalist mõistmist ja taasesitamist, näiteks tuli õpilasel valida loendist õige variant ja lõpetada lause. Selleks tuli meenutada kuuldud loos sisaldunud infot:

Kuula tähelepanelikult teksti ja tõmba õigele vastusele joon alla. Külarahvas arvas, et Matsi päästsid ...

Vastusevariandid olid inglid; head inimesed; haldjad.

Õigele vastusele haldjad oli kuuldud tekstis sõnaselgelt osutatud: Külarahvas arvas, et küllap need olid metshaldjad, kes Matsi soost ...

2014. aasta kuulamisülesande lahendus erines 2013. aasta omast selle poolest, et iga väite järel ei pakutud õpilasele mitte kolme vastusevarianti, vaid õpilasel tuli teha üks õige valik ülesande lõpus toodud loetelust. Seejuures olid valikud esitatud vastusepaaridena ning õiges käändes, mis muutis otsustamise mõnevõrra kergemaks. Üks selline tekstil põhineva info leidmise alaülesanne oli järgmine:

Kuula teksti ja täida selle põhjal lüngad. Õiged vastused vali lünkteksti lõpust. Kirjuta vastused lünka täpselt samas vormis, nagu need on teksti lõpus.

Vanal ajal keerutati tuletegemiseks tulepuuri pulka vastu pehmemat puuplaati, kuni ... 
Lünka sobiv vastusepaar, millest õpilasel tuli teha valik, oli: tulepuur hakkas hõõguma - puutolm hakkas hõõguma.

Kuuldud tekstis oli vastust sisaldav lause järgmine:

Vibunööri vahele keeratud tulepuuri pulka keerutati vibu edasi-tagasi liigutades ja vastu pehmemat puuplaati surudes, nii et puutolm hõõguma hakkaks.

Sõnasõnalise tasandi tekstimõistmisülesanneteks liigitati ka sellised ülesanded, mis nõudsid õpilaselt peale tekstis sisalduva info äratundmise ja meenutamise ka tekstile toetuvate lihtsamate järelduste tegemist. Näiteks pidi õpilane 2015. a tasemetöös teksti põhjal aru saama, et asjade all mõeldakse eespool tekstis jutuks olnud mööbliesemeid.

Otsusta kuuldud teksti põhjal, kas väide on õige või vale. Tee vastavasse kasti rist. Väide: Kärbse arvates püsis mööbel laes liimiga.

Tekstis olev lause väite hindamiseks oli:

"Liimiga! Liimiga! Vaat, kuidas inimesed oma asju laes kinni hoiavad."

Kõikides tasemetöödes leidus ka selliseid ülesandeid, kus õpilane pidi lugema tabelit ja/või diagrammi ning saama aru seal esitatud infost. Nendest määrati sõnasõnalise tasandi ülesanneteks sellised, mis eeldasid oskust lugeda tabelist või diagrammilt infot ja täita lüngad, kuid ei nõudnud andmete võrdlemist ning seoste või järelduste tegemist. Näiteks kui õpilane pidi tabelist kokku loendama kõik seal esinenud nimetused või õpilaste nimed, mis ta lünkadesse kirjutas:

Talvel võib toidumajade juures kohata kokku ... tihaseliiki. (2015)

Kokku kuulub kooli võistkonda (mitu?) ... õpilast. (2013)

Analüüsides kolme aasta eesti keele tasemetööde keerukamaid ülesandeid, selgus, et umbes pooled 2013. ja 2015. aasta tekstimõistmisülesannetest olid järeldava tasandi ülesanded (2013. aastal 52,4\% ja 2015. aastal 42,9\%). Seevastu 2014. aasta tasemetöös oli selliseid ülesandeid vähem - ligi veerand (24\%) kõikidest tekstimõistmisülesannetest. Kuigi kolme aasta järeldava tasandi ülesanded olid tekstipõhised, eeldasid need õpilaselt ka vähest järeldus- või analüüsioskust. Praeguses analüüsis liigitati järeldava tasandi tekstimõistmisülesannete hulka sellised tabeli või diagrammi lugemise ülesanded, kus õpilane pidi esmalt võrdlema esitatud infot ning leidma siis lünkadesse õiged vastused:

6 o meetri teatejooksu võistkonda (2 poissija 2 tüdrukut) kuuluvad ... (2013) Eestis kõige tavalisem talvine aialind on ... (2015)

Järeldava tasandi ülesannete hulgas oli ka selliseid, kus õpilane pidi vastuse saamiseks kasutama varasemaid teadmisi. Näiteks tuli 2014. aasta diagrammi ülesandes vastuse saamiseks teisendada diagrammil esitatud minutid tundideks, nt Poisid kasutavad arvutit õppimiseks päevas keskmiselt ... tundi. Sarnast analüüsimise ja taustteadmiste kasutamise oskust nõudis ka 2014. aasta kuulamisülesanne, kus õpilane pidi täitma lünga kuuldu põhjal (Eestis võeti tikud kasutusele ... sajandil); teises ülesandes oli tekstis esitatud aastaarv ja õpilane pidi eelteadmisi kasutades tegema teisenduse (nt 1925. aasta on 20. sajand). 
Tasemetööd sisaldasid ka selliseid ülesandeid, mis eeldasid õpilaselt järelduste tegemist teksti põhjal ning eri tekstiosade analüüsimist ja seostamist. Näiteks tuli 2013. aasta tasemetöös paigutada segiaetud tekstilõigud õigesse järjekorda (teksti pikkus oli 88 sõna). Teksti analüüsimist, selle üle arutlemist ja saadud info kasutamist läks tarvis ka teises sama aasta tasemetöö ülesandes: õpilane pidi moodustama teksti põhjal neli küsimust.

Tasemetööde kõige keerukamatest tekstimõistmisülesannetest liigitus ainult üks kõrgeimaks ehk hindava tasandi ülesandeks. Selles 2013. aasta ülesandes tuli õpilasel varasemaid teadmisi rakendades otsustada, mis liiki on kuulamistekst, ning teha vastusevariantide hulgast õige valik, nt Kuuldud lugu oli ... (muistend, muinasjutt, valm). Kuigi ülesandes olid valikud õpilasele ette antud, liigitati see ülesanne kõrgeima tasandi tekstimõistmisülesandeks, sest õpilane pidi kasutama taustteadmisi eri tekstiliikide ja nende tunnuste kohta, seejärel otsustama, mis tunnused esinesid kuuldud tekstis, ja lõpuks määrama tekstiliigi.

Lisaks huvituti, kui palju kasutati kolme aasta tasemetöödes ülesandeid, millele õpilane 1) leidis vastuse etteantud variantide hulgast, 2) täitis teksti põhjal lüngad, 3) järjestas segiaetud tekstilõigud, 4) sõnastas ise vastused. Tulemused on joonisel 2.

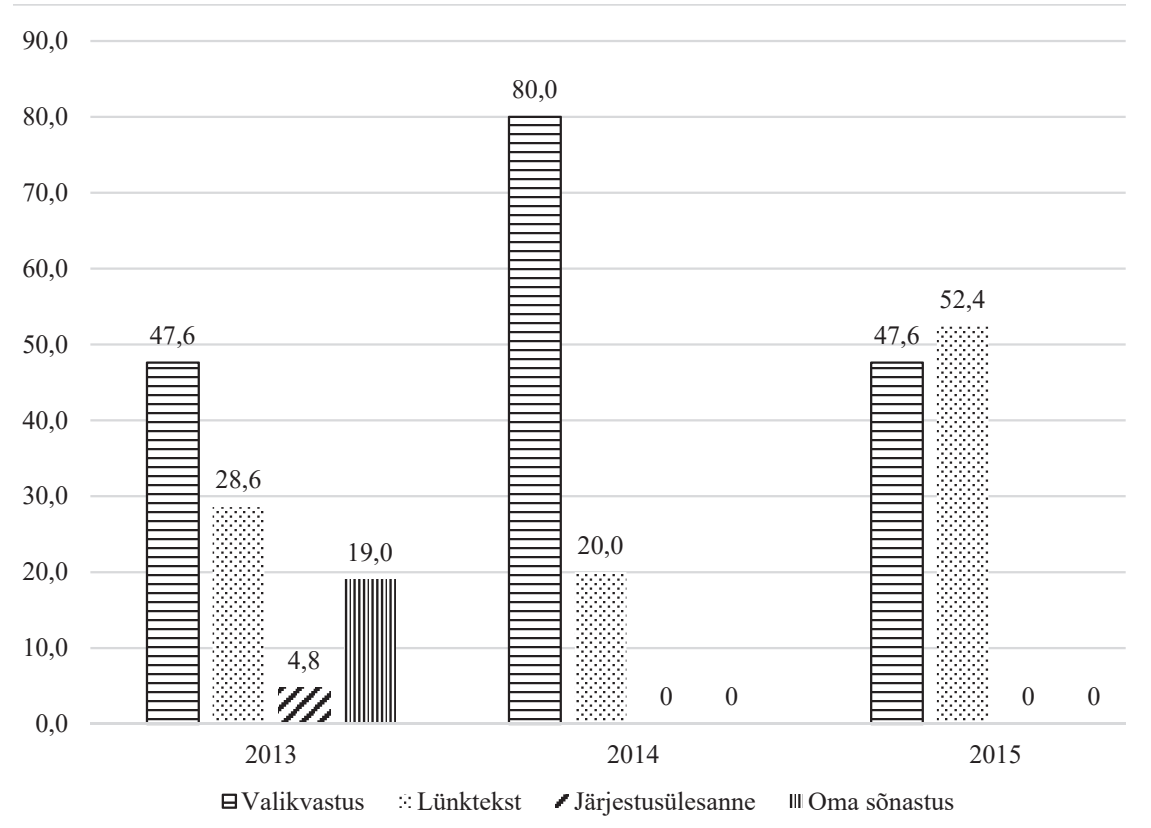

Joonis 2. Tasemetööde ülesannete tüübid

Selgus, et suur hulk ülesannetest oli sellised, kus õpilane sai kogu info tasemetöö tekstist ega pidanud vastamisel rakendama eelteadmisi. Enamasti olid õpilastele ette antud ka vastusevariandid. Nii oli 2014. aasta tasemetöös valikvastusülesandeid $80 \%$ ja 2015. aasta tasemetöös ligikaudu 50\%. Ülejäänud ülesannetes pidi õpilane panema loetud teksti põhjal lünka sobiva sõna. Lisaks sisaldas 2013. aasta tasemetöö ülesannet, kus õpilasel tuli järjestada segiaetud tekstilõigud. Keerukamaid tekstimõistmisülesandeid, kus õpilane pidi vastuse koostamisel kasutama 
tekstiloomeoskust, esines samuti ainult 2013. aasta tasemetöös: õpilasel tuli moodustada loetud teksti põhjal neli küsimust: Kes ...? Millal ...? Kuidas ...? Miks ...? Sellist tüüpi alaülesannete osakaal oli 2013. aastal 19,05\%.

\section{Arutelu}

Et hinnata õpilaste tekstimõistmist eri tasandite kaupa, on oluline kasutada eri tüüpi ja eri raskusastmega ülesandeid. Selles artiklis analüüsiti 6. klassi eesti keele riiklike tasemetööde tekstimõistmisülesandeid aastatel 2013-2015. Ilmnes, et tasemetööde tekstimõistmisülesanded ei ole piisavalt mitmekesised, et selgitada välja õpilaste tekstimõistmisoskused eri tasandite kaupa. Paljudes ülesannetes keskenduti oskusele meenutada tekstis sisalduvat infot. 6. klassi õpilastele jõukohast hindamist ja kriitilist mõtlemist nõudvaid ülesandeid oli kolme aasta tasemetöödes vähe. Samas ilmnes tendents, et tasemetööde tekstid (lause ja sõna keskmise pikkuse järgi) on muutumas lihtsamaks.

Tasemetöid iseloomustavaks tunnuseks võib pidada seda, et suur hulk ülesandeid on suunatud madalaima tekstimõistmistasandi kontrollimisele, st kui hästi mõistab õpilane tekstis sisalduvat lihtsat ja selgelt esitatud infot. Faktide meenutamist nõudvaid ülesandeid oli kõige rohkem 2014. aasta tasemetöös, kuid palju leidus neid ka teiste aastate töödes (umbes 50\% ülesannetest). Võrdluseks oli PISA 2009. a lugemistestis madalama tasandi, st info hankimist eeldavate ülesannete osakaal umbes $25 \%$ (vt Tire jt 2010). PISA ülesannete hulgas oli nii lihtsamaid kui ka keerukamaid ülesandeid. Õpilased pidid tundma sünonüüme ja valima mitme sarnase teabeühiku seast õige variandi. Ülesanded muutis keerukamaks see, et vastusevariante ei antud õpilasele ette. Seevastu eesti keele riiklikes tasemetöödes mõõdetakse õpilaste sõnasõnalist tekstimõistmist ülesannetega, kus vastusevariandid on enamasti ette antud. Kui vastuste sõnastus on sarnane teabega, mis sisaldub tekstis, lihtsustab see valiku tegemist (NAEP 2008). Ka tabelite ja diagrammide lugemise ülesannete hulgas oli päris palju küsimusi, mis eeldasid vastajalt konkreetse infoühiku leidmist. Ometi võimaldaks jooniste lugemine arendada nii õpilaste analüüsi- kui ka järeldusoskust. Tasakaal eri tasandi tekstimõistmisülesannete vahel võimaldaks eristada õpilasi, kes loevad teksti pinnapealselt, õpilastest, kes mõistavad teksti sügavuti, oskavad loetu üle arutleda ja saadud teadmisi rakendada (Applegate jt 2002).

Kõigi kolme aasta tasemetöödes leidus järeldava tasandi tekstimõistmisülesandeid, milles õpilased pidid võrdlema andmeid, looma seoseid ning tegema järeldusi. Samas olid need ülesanded üsna lihtsad ning tõenäoliselt allpool 6. klassi õpilaste eakohast arengutaset (vt Kibui 2012). Selles eas õpilastele on jõukohane teha keerukamaid järeldusi loetu kohta, tõlgendada ja hinnata tegelaste käitumist, selgitada teksti mõtet ning hinnata autori eesmärki ja kavatsusi. Lisaks suudavad õpilased moodustada loetud tekstile ja eelteadmistele toetudes lühemaid ja pikemaid lõike (NAEP 2008). Riikliku tasemetöö järeldava tasandi ülesannetes olid aga valikud enamasti ette antud ning analüüsi või järelduste tegemisel tuli toetuda üksnes tekstis esitatud infole. Ainult mõni üksik kõigi kolme aasta testide alaülesanne eeldas õpilaselt eelteadmiste sidumist tekstist saadud infoga. Nii näiteks pidi õpilane 2013. aasta tasemetöö kuulamisülesandes teadma varasemast, et kukk on 
kodulind: tekstis oli räägitud kukest ja vastusevariantide seas oli esitatud kodulind. Selliseid ülesandeid, kus õpilane pidi ise vastuse konstrueerima (nt küsimuse moodustama), esines ainult 2013. aasta tasemetöös. Applegate jt (2002) on leidnud, et ülesanded ja küsimused, millel pole üht õiget vastust ja mis tuleb õpilasel endal tekstile toetudes välja mõtelda, mõõdavad paremini võimekust teksti üle arutleda ning kasutada saadud teadmisi oma arvamuse põhjendamisel. Seevastu NAEP testis (2008) tuli õpilasel ligikaudu $45 \%$ ülesannetest esitada lühivastus ja $15 \%$ ülesannetest moodustada pikemaid lõike. Siinse uurimuse raames analüüsitud tasemetöödes seda tüüpi ülesanded puudusid.

Uurimistulemustest selgus samuti, et ainult 2013. aasta tasemetöö sisaldas kõigi kolme (sõnasõnalise, järeldava ja hindava) tasandi tekstimõistmisülesandeid, kusjuures kõrgeimat tekstimõistmistasandit hinnati vaid ühe alaülesandega. Seevastu oli selles tasemetöös palju sõnasõnalise ja järeldava tasandi alaülesandeid, näiteks tuli järjestada segiaetud tekstilõigud. Sarnaselt madalama tasandi ülesannetega pidi õpilane ka hindava tasandi ülesandes valima õige vastuse mitmese valiku hulgast. See tähendab, et ülesanne oli ópilase jaoks lihtne ja ta ei pidanud pingutama, kuigi kõrgeima tasandi ülesanne oleks seda võimaldanud. Kognitiivse arengu järgi on 12-13-aastase lapse töömälumaht ja eelteadmised piisavalt arenenud, et teha sisukaid järeldusi ning tõlgendada ja hinnata tekstis sisalduvat infot (Kibui 2012). Et arendada kriitilist mõtlemist, tuleks esitada lastele keerukamaid küsimusi, mis nõuavad eelteadmiste rakendamist, järelduste tegemist ning oskust loetut kriitiliselt hinnata (Mayer 2002). Oluline on ärgitada last mõtlema ja ise teksti looma (Nystrand jt 2003). Kui aga tasemetööd koosnevad valdavalt lihtsamatest ülesannetest, siis võivad õpetajad sellest eeskuju saada ja kasutada lugemistundides eelkõige selliseid lugemisülesandeid, mis arendavad madalama tasandi oskusi.

Lugemistestidega, mis sisaldavad sõnasõnalise, järeldava ja hindava tasandi ülesandeid, on võimalik välja selgitada õpilaste tegelik arengutase ja selle puudujäägid (Hogan jt 2011). Siinses artiklis analüüsitud eesti keele tasemetööde ülesanded võimaldasid mõõta õpilaste oskust mõista ja analüüsida tekstis esitatud selgesõnalist infot ning teha teksti põhjal lihtsamaid järeldusi. Ometi ei saadud nende testidega teada, kui hästi suudavad Eesti keskastme õpilased infot kriitiliselt hinnata. Samuti ei saa tasemetööde alusel teha järeldusi selle kohta, kas õpetajad on täitnud põhikooli riiklikus õppekavas (2011) sätestatud eesmärgi arendada teise kooliastme lugemistundides õpilaste kõrgema tasandi tekstimõistmisoskusi. Tasemetöö tulemuste põhjal võib rutakalt pidada oskuslikeks tekstimõistjateks selliseid õpilasi, kes ei oska teksti süvitsi lugeda ega arutleda tekstis sisalduvate probleemide üle. Ka võimest argumenteerida ning siduda eelteadmisi uue infoga võib õpilastel vajaka jääda (vt Broek, Espin 2012). Tulemus võib olla see, et lapsed käsitlevad lugemist kui mehaanilist ja töömahukat protsessi, mitte kui võimalust infot kriitiliselt analüüsida ja enda arenguks kasutada (Applegate jt 2002).

Tekstimõistmistasandite hindamine on vajalik, et selgitada välja õpilaste võimalikud raskused tekstist arusaamisel. Praeguse uurimuse põhjal saab teha mitmeid sisukaid järeldusi ning anda soovitusi õpetamise planeerimiseks, tekstimõistmise arendamiseks ja seda toetavate strateegiate kujundamiseks.

1. Õpilase kujunemisel oskuslikuks tekstimõistjaks ei piisa ainult madalama tasandi ülesannetest. Riiklikes tasemetöödes tuleks saavutada tasakaal eri tasandite tekstimõistmisülesannete vahel, et arendada õpilaste lugemisoskust harmooniliselt. 
2. Arvestades tänapäevaseid käsitlusi tekstimõistmise kõrgema ja madalama tasandi kohta (nt Broek, Espin 2012), tuleks neid teadmisi rakendada nii seniste tasemetööde ülesannete parendamises kui ka uute koostamises. Tasemetöödes on oluline arvestada õpilaste eakohase kognitiivse arengu ja tekstimõistmistasanditega.

3. Tasemetööd on vahend, millega suunata eesti keele õpetajate tegevusi. Kui tasemetöödes nõutakse õpilaselt kõrgema tasandi oskuste rakendamist, pööravad õpetajad lugemistundides tõenäoliselt rohkem tähelepanu nende oskuste kujundamisele ning õpilaste kõrgeima tasandi tekstimõistmine paraneb.

4. Kuigi praegused tasemetööd ei võimalda välja selgitada õpilaste tekstimõistmist eri tasanditel, võimaldavad nad lihtsal viisil hinnata ning võrrelda õpilaste teadmisi tekstimõistmise madalamatel tasanditel.

\section{Viidatud kirjandus}

Angosto, Alberto; Sánchez, Patricia; Álvarez, Maria; Cuevas, Irene; León, Jose Antonio 2013. Evidence for top-down processing in reading comprehension of children. - Psicologia Educativa, 19 (2), 83-88. https://doi.org/10.1016/S1135-755X(13)70014-9

Applegate, Mary DeKonty; Quinn, Kathleen Benson; Applegate, Anthony J. 2002. Levels of thinking required by comprehension questions in informal reading inventories. - The Reading Teacher, 56 (2), 174-180.

Babic, Dragica Pavlovic; Baucal, Aleksandar 2011. The big improvement in PISA 2009 reading achievements in Serbia: Improvement of the quality of education or something else? - CEPS Journal: Center for Educational Policy Studies Journal, 1 (3), 53-74.

Basabara, Deni; Yovanoff, Paul; Alonzo, Julie; Tindal, Gerald 2013. Examining the structure of reading comprehension: Do literal, inferential, and evaluative comprehension truly exist? - Reading and Writing, 26 (3), 349-379. https://doi.org/10.1007/ $\underline{\text { s11145-012-9372-9 }}$

Broek, Paul van den; Espin, Christine A. 2012. Connecting cognitive theory and assessment: Measuring individual differences in reading comprehension. - School Psychology Review, 41 (3), 315-325.

Bursuck, William D.; Damer, Mary 2011. Teaching Reading to Students Who are at Risk or Have Disabilities. 2nd ed. Upper Saddle, NJ: Pearson.

Butcher, Kirsten R.; Kintsch, Walter 2012. Text comprehension and discourse processing. I. B. Weiner, A. F. Healy, R. W. Proctor (Eds.), Handbook of Psychology. 2nd ed. Somerset, NJ: Wiley, 578-605.https://doi.org/10.1002/9781118133880.hop204021

Carretti, Barbara; Cornoldi, Cesare; De Beni, Rossana; Romanò, Marta 2005. Updating in working memory: A comparison of good and poor comprehenders. - Journal of Experimental Child Psychology, 91 (1), 45-66. https://doi.org/10.1016/j.jecp.2005.01.005

Hogan, Tiffany; Bridges, Mindy Sittner; Justice, Laura M.; Cain, Kate 2011. Increasing higher level language skills to improve reading comprehension. - Focus on Exceptional Children, 44, 1-20.

Kibui, Agnes Wanja 2012. Reading and Comprehension in the African Context: A Cognitive Enquiry. Limuru, KEN: Zapf Chancery Publishers Africa Ltd, 13-71.

Kostons, Danny; Werf, Greetje van der 2015. The effects of activating prior topic and metacognitive knowledge on text comprehension scores. - British Journal of Educational Psychology, 85 (3), 264-275. https://doi.org/10.1111/bjep.12069

Margutti, Piera; Drew, Paul 2014. Positive evaluation of student answers in classroom instruction. - Language and Education, 28 (5), 436-458. https://doi.org/10.1080/ $\underline{09500782.2014 .898650}$ 
Mayer, Richard E. 2002. Traditional versus meaningful learning. - Theory into Practice, 41 (4), 226-232. https://doi.org/10.1207/s15430421tip4104 4

Mercer, Neil 2008. The seeds of time: Why classroom dialogue needs a temporal analysis. - The Journal of the Learning Sciences, 17 (1), 33-59. http://dx.doi. org/10.1080/10508400701793182

Mercer, Neil 2013. The social brain, language, and goal-directed collective thinking: A social conception of cognition and its implications for understanding how we think, teach, and learn. - Educational Psychologist, 48 (3), 148-168. https://doi.org/10.10 80/00461520.2013.804394

Mercer, Neil; Dawes, Lyn 2014. The study of talk between teachers and students, from the 1970 s until the 2010s. - Oxford Review of Education, 40 (4), 430-445.

NAEP Govering 2008. Reading Framework for the 2009 National Assessment of Educational Progress. Washington: U. S. Department of Education.

Nation, Kate; Cocksey, Joanne; Taylor, Jo S. H.; Bishop, Dorothy V. M. 2010. A longitudinal investigation of early reading and language skills in children with poor reading comprehension. - Journal of Child Psychology and Psychiatry, 51 (9), 1031-1039. https:// doi.org/10.1111/j.1469-7610.2010.02254.X

Nystrand, Martin; Wu, Lawrence L.; Gamoran, Adam; Zeiser, Susie; Long, Daniel A. 2003. Questions in time: Investigating the structure and dynamics of unfolding classroom discourse. - Discourse Processes, 35 (2), 135-198. https://doi.org/10.1207/ S15326950DP3502 3

Oakhill, Jane; Yuill, Nicola 1996. Higher order factors in comprehension disability: Processes and remediation. - C. Cornoldi, J. V. Oakhill (Eds.), Reading Comprehension Difficulties. Mahwah, NJ: Lawrence Erlbaum Associates, 69-92.

OECD 2008. Lugemisoskus. PISA 2009 raamdokument. Tallinn: REKK.

Pianta, Robert C.; Hamre, Bridget K. 2009. Conceptualization, measurement, and improvement of classroom processes: Standardized observation can leverage capacity. - Educational Researcher, 38 (2), 109-119. https://doi.org/10.3102/0013189X09332374

Pintrich, Paul R. 2002. The role of metacognitive knowledge in learning, teaching, and assessing. - Theory Into Practice, 41 (4), 219-225. https://doi.org/10.1207/ S15430421tip4104 3

Põhikooli riiklik õppekava 2011. Vabariigi Valitsuse 06. jaanuari 2011. a määrus nr 1. https:// www.riigiteataja.ee/akt/114012011001?leiaKehtiv (15.9.2016).

Ryan, Gery W.; Bernard, H. Russell 2000. Data management and analysis methods. N. K. Denzin, Y. S. Lincoln (Eds.), Handbook of Qualitative Research. 2nd ed. Thousand Oaks, CA: Sage, 769-802

Tire, Gunda; Puksand, Helin; Henno, Imbi; Lepmann, Tiit 2010. PISA 2009 - Eesti tulemused. Tallinn: Innove. http://hdl.handle.net/10062/40802

Thompson, Paul 2008. Learning through extended talk. - Language and Education, 22 (3), 241-256. https://doi.org/10.1080/09500780802152507

Roe, Betty; Smith, H. Smith; Burns, Paul C. 2012. Teaching Reading in Today's Elementary Schools. 11th ed. Belmont, CA: Wadsworth, Cengage Learning.

Schroeder, Sascha 2011. What readers have to do: Effects of students' verbal ability and reading time component on comprehension with and without text availability. Journal of Educational Psychology, 103 (4), 877-896. https://doi.org/10.1037/ aoo23731

Sencibaugh, Joseph M.; Sencibaugh, Angela M. 2015. The effects of questioning the author on the reading comprehension of middle school students. - Reading Improvement, 52 (3), 85-92.

Uibu, Krista; Padrik, Maarika; Tenjes, Silvi 2016. Klassiõpetajate keele- ja suhtluseeskuju hindamine emakeeletunnis struktureeritud vaatluse teel. [Evaluation of primary school teachers' exemplar-based linguistic communication based on structured 
observation.] - Eesti Haridusteaduste Ajakiri, 4 (1), 226-257.https://doi.org/10.12697/

eha.2016.4.1.08

Võgotski, Lev 2014 [1934]. Mõtlemine ja kõne. [Thinking and Speech.] Tartu: Ilmamaa.

\section{Võrguviited}

Üleriigiline tasemetöö 2013, eesti keel, 6. klass. http://www.innove.ee/et/yldharidus/tasemetood/tasemetoode-materjalid (8.8.2016).

Üleriigiline tasemetöö 2014, eesti keel, 6. klass. http://www.innove.ee/et/yldharidus/tasemetood/tasemetoode-materjalid (8.8.2016).

Üleriigiline tasemetöö 2015, eesti keel, 6. klass. http://www.innove.ee/et/yldharidus/tasemetood/tasemetoode-materjalid/tasemetoode-materjalid-2015 (8.8.2016).

Triinu Kärbla (Tartu Ülikooli haridusteaduste doktorant) väitekirja teema on õpilaste tekstimõistmistasemete hindamine ja tekstimõistmise toetamine õpetamismeetoditega. Salme 1a, 50103 Tartu, Estonia

triinu.karbla@ut.ee

Krista Uibu (Tartu Ülikool) peamised uurimisvaldkonnad on õpilaste emakeeleoskused, õpetamismeetodite dünaamika ja õpetajate õpetamistegevused. Tema hiljutised uurimused on seotud põhikooli õpilaste teksti mõistmisega ja õpetajate õpetamistegevustega. Uurimusi iseloomustavaks tunnuseks on suured valimid, pikilõikelised uurimused ja mitmetasandilised analüüsid. Salme 1a, 50103 Tartu, Estonia

krista.uibu@ut.ee

Mairi Männamaa (Tartu Ülikool) uurimused on seotud erinevate sihtrühmade (õpiraskustega lapsed, enneaegsed ja traumasid läbielanud lapsed) kognitiivse arenguga. Lisaks on ta uurinud laste kognitiivsete funktsioonide ja akadeemilise edukuse seoseid. Neist viimane uurimus keskendus põhikooli õpilaste eneseregulatsiooni, kognitiivsete ja käitumuslike aspektide arengule ning nende seostele matemaatika- ja lugemisoskustega.

Salme 1a, 50103 Tartu, Estonia

mairi.mannamaa@ut.ee 


\title{
ANALYSIS OF THE COMPREHENSION TASKS OF NATIONAL STANDARDISED TESTS OF ESTONIAN LANGUAGE
}

\author{
Triinu Kärbla, Krista Uibu, Mairi Männamaa
}

University of Tartu

Text comprehension is a complex process where low- and high-level skills are likely to interact. In this article the comprehension tasks of national standardised tests of Estonian language for Grade 6 in 2013-2015 are analysed to detect levels of text comprehension in standardised tests. We found that the comprehension tasks in standardised tests are mostly focused on factual knowledge. Furthermore, $76 \%$ of questions in the national standardised test in 2014 and $57.1 \%$ in 2015 consisted of tasks which measured children's ability to recall the details from the read or heard text. In 2013, such tasks comprised $42.9 \%$ of the national standardised test. We found only one task (in 2013) which demanded the highest skills - implementing pre-knowledge into the evaluation process. Thus, the tasks used in standardised test are not wide-ranging enough to determine students' skills at different levels of text comprehension. As long as national standardised tests consist mostly of tasks that require readers' memory, teachers also concentrate mainly on supporting students' lower-level text comprehension skills. Therefore, there may not be enough attention devoted to developing the students' high-level skills. As text comprehension at higher level is one of the most important competences students must acquire for successful academic and lifelong growth, teachers should concentrate more on supporting these skills.

Keywords: national standardised tests, text comprehension level, primary school, Estonian language 